\title{
Knowledge and attitude of community towards trachoma and trichiasis in Arba Minch Zuria district, Gamo Zone, Southern Ethiopia, 2019
}

Chuchu Churko ( $\nabla$ churkochuchu2005@gmail.com )

Arba Minch University https://orcid.org/0000-0002-9132-9471

Mekuria Asnakew Asfaw

Arba Minch University

Zerihun Zerdo

Arba Minch University

\section{Research}

Keywords: trachoma, Arba Minch zuria, trichiasis, Ethiopia

Posted Date: May 13th, 2021

DOI: https://doi.org/10.21203/rs.3.rs-498270/v1

License: (c) (1) This work is licensed under a Creative Commons Attribution 4.0 International License.

Read Full License 


\section{Abstract \\ Background}

Trachoma is a preventable and treatable disease caused by Chlamydia trachomatis which is the leading cause of blindness in the world affecting mostly the poorest community. Despite so many intervention undertaken on prevention and control for trachoma, Ethiopia is failed to achieve 2020 elimination goal for trachoma. We hypothesized that the knowledge of communities towards trachoma was inadequate in the study area.

\section{Methods}

a community based cross sectional study was conducted in Arba Minch zuria district from December 2019 to June 2020. The total sample size was allocated by probability proportional to size to each kebele based on the number of households they had. Then, systematic random sampling was employed to select 811 study participants from the five kebeles. Data were collected using a pretested interviewer administered structured questionnaire and then entered into EPI/INFO version 7 and exported to SPSS V20 for analysis.

\section{Findings:}

All of the respondents heard about trachoma. Less than one forth $185(23.2 \%)$ of the study subjects had adequate knowledge towards trachoma. One hundred forty eight (18.6\%) strongly agreed that trachoma can be transmitted through gene. On the other hand, 240 (30.1\%) of the respondents were unsure that trichiasis patients may loss vision if not operated. Factors like education, occupation, walking distance from home to clean water source and wealth index were significantly associated with knowledge status of the participants.

\section{Conclusion}

the proportion of people who had adequate knowledge about trachoma and trichiasis was low. Attention should be given by the district health office, regional government and different stakeholders, who designing and implementing trachoma elimination programs especially improving awareness of community regarding trachoma and trichiasis. Interventions with the F and E components of SAFE strategy are also strongly recommended.

\section{Introduction}

Trachoma is a preventable and treatable disease caused by Chlamydia trachomatis which is the leading cause of blindness in the world affecting mostly the poorest community. Repeated infection of children 
with Chlamydia trachomatis can lead to scarring of the conjunctiva, causing entropion in adults as the eyelid turns inward, and trichiasis as the eyelashes deviate inward and touch the globe. Damage to the cornea from trichiasis, as well as abnormal conjunctiva, can result in vision loss (1).

Trachomatous trichiasis (TT) is defined as in-turning of eyelashes to the eye globes and repeated touching of the eyelashes leads to scaring of the cornea which end up to visual impairment/permanent blindness. It remains the leading infectious cause of blindness worldwide (2). Trachomatous trichiasis is a consequence of progressive conjunctival scarring caused by recurrent infection with Chlamydia trachomatis. It causes painful corneal abrasion, introduces infection, and alters the ocular surface, eventually leading to irreversible blindness from corneal opacification (3).

The world Health Organization simplified classification of trachoma infection as Follicular trachoma (TF), inflammatory trachoma (TI), trachomatous scaring (TS), Trachomatous Trichiasis (TT) and corneal opacity (CO). TF is described as (of at least $0.5 \mathrm{~mm}$ ) in the upper tarsal conjunctiva; Pronounced inflammatory thickening of the tarsal. TI is when conjunctiva that obscures more than half of the deep normal tarsal vessels. TS is described as the presence of scarring in the tarsal conjunctiva and $\mathrm{CO}$ means the presence of easily visible corneal opacity which obscures at least some of the pupil (4).

The World Health Organization has launched an initiative to eliminate blinding trachoma by the year 2020 using the SAFE strategy: Surgery, Antibiotic, Facial Cleanliness and Environmental improvement (5). Surgical correction of the upper eyelid using tarsal rotation procedure is the most effective intervention for trichiasis. Trachomatous Trichiasis surgery treatment is provided free or subsidized in most trachoma endemic settings (6).

The World Health Organization (WHO) recommends corrective eyelid surgery to reduce the risk of visual impairment from TT. The surgery involves an incision through the eyelid parallel to and a few millimeters above the lid margin. The terminal portion of the lid is externally rotated and sutured in the corrected position (7). In the two most commonly used procedures, a horizontal incision is made either full thickness (bilamellar tarsal rotation) or partial thickness (posterior lamellar tarsal rotation) through the upper lid and sutures then place to rotate the lower part of the upper lid outwards (8).

According to world health organization (WHO) report in 2003 there were 84 million active trachoma and 7.6 million TT cases globally (9). In 2009, Mariette et al found that the burden of active trachoma and TT cases were 41 million and 802 million respectively.

Trachoma remains a problem in the poorest societies of the world. As of 2014, an estimated 21 million people were afflicted with active trachoma, 7.3 million of whom have trichiasis and 2.2 million of whom are either completely blind or severely visually impaired. The majority of this blinding trachoma occurs in African countries (10). According to the WHO weekly epidemiological record 2019, 142.2 million people live in trachoma endemic areas and 2.5 million people requires urgent surgery to trachomatous trichiasis, the late stage of blinding trachoma (11). 
The pain and photophobia from trichiasis may also lead to disability, limiting engagement with productive household and agricultural activities even prior to the development of visual impairment. This can result in loss of income and additional economic pressure on often already deprived households. Habtamu et al reported that TT significantly reduces participation in productive household, outdoor, agricultural and leisure activities, even prior to the development of visual impairment (12). Moreover, they found that TT cases experienced considerably more difficulty in performing tasks and required extra assistance, compared to their neighbors without TT (12). Other studies have shown that trichiasis causes considerable functional and physical impairment, inability to work and earn an income (13).

Based on the study conducted in Narok on trachoma and its control, majority of the community who interviewed had good knowledge towards trachoma and its transmission. Failure to wash face and bathe regularly, sharing of water basins and towels for face washing, traditional methods of trachoma treatment and dirty household environment were significantly associated with trachoma infection transmission (14).

Studies from different part of the world reported that people did not know that children are most susceptible to trachoma infection due to their tendency to easily get dirty and the disease is not felt until adulthood. There is also poor knowledge to many factors that are directly linked to trachoma like, absence of latrine, lack of water, flies, close proximity to cattle and crowding (15).

In Tanzania a qualitative study showed that there was awareness of trachoma and its basic symptoms; however understanding towards the etiology and prevention was poor. They reported that trachoma was attributed to pollen, dust and smoke. In the country traditional medicines were often used for treatment of conjunctival inflammation, with the most commonly using a rough leaf to scratch the inside of the eyelid until it bleeds (16).

In 2017, 70 million people lived in trachoma endemic areas in Ethiopia; that's $44 \%$ of the global burden of active trachoma (17). Trachoma is the second most common cause of blindness in Ethiopia exceeded only by trachoma where trichiasis affects $3 \%$ of people above 14 years of age (18). According to the national survey conducted in 2006 , trachoma accounts for $11.5 \%$ of all blindness and $7.7 \%$ of people with low vision. It is estimated that over 138,000 people in Ethiopia are already blinded by this disease (19).

In the Southern Nations, Nationalities and People's Region (SNNPR), where ORBIS implements its rural program and trachoma control initiatives, the prevalence is even higher. Based on evidence generated from district baseline trachoma surveys in ORBIS supported rural project areas, the prevalence of active trachoma ranges from $22-56 \%$ and that of trachomatous trichiasis from $1.1-6.4 \%$ (20). More recent evidence showed that Arba Minch zuria district have the highest TT backlog in Gamo zone, Southern Ethiopia (20).

Despite the scale-up of different intervention done in Ethiopia like annual and biannual mass drug administration for trachoma and surgical services in recent years, the disease is still public health 
problem affecting the people living remote kebeles and who are poor economic status. We hypothesized that the disease is public still public health problem because of inadequate knowledge and attitude towards trachoma prevention and control measures. Therefore, the aim of this study was to assess knowledge and attitude among communities living in Arba Minch zuria district, Gamo zone, Southern Ethiopia, 2019.

\section{Methods And Materials}

\section{Study setting and design}

Cross sectional study was conducted from December 2019 to June 2020 in Arba Minch zuria district in Gamo zone which has high prevalence of TT backlog. According to ORBIS international Ethiopia report the district had estimated TT backlog of 511. Gamo zone is one of the zones in the SNNP region of Ethiopia. It is recently departed from Goffa zone, formerly known as Gamo Goffa zone. The zone is located $505 \mathrm{~km}$ south from Addis Ababa, having 13 districts and 4 city administrations. According to the 2007 Ethiopian central statistics agency census, the zone had a total population of 1,341,901 of which 668,230 were men and 673,671 were women. Majority of the population $1,292,653(96.33 \%)$ live in rural area. The current profile indicated that there are 5 hospitals, 33 private clinics and 53 health centers in recently formed Gamo zone.

\section{Source and study population}

\section{Source population}

individuals aged 18 years and above in the selected district.

\section{Study population}

randomly selected individuals aged 18 years and above in the selected district.

\section{Eligibility criteria}

\section{Inclusion criteria}

all persons aged 18 years and above in randomly selected kebeles were eligible for this study.

\section{Exclusion criteria}

those individuals who were severely ill and absent during data collection period were excluded from the study.

\section{Sample size}

Single population proportion formula was used to calculate sample size by considering the following assumptions: 


\section{$\mathrm{N}=\underline{\mathrm{z}}^{2} \underline{\alpha / 2} * \mathrm{P}[1-\mathrm{P}]$}

\section{$d^{2}$}

Where,

$\mathrm{N}=$ initial sample size

$Z_{a / 2}=$ significance level at $95 \%$ confidence interval $=1.96$

$P=60 \%$ proportion people who had adequate knowledge towards trachoma (21),

Degree of margin $=5 \%$

$N=1.96^{2 *} 0.6(1-0.6) /(0.05)^{2}=3.8416 * 0.24 / 0.0025=0.922 / 0.0025=368.79$

By adding design effect of 2 and $10 \%$ non-response rate, the final sample size was 811 .

\section{Sampling procedure}

Arba Minch Zuria district was purposively selected since it had high TT backlog when compared to others and $25 \%$ of the total kebeles was selected to be representative of the data. The total number of households was obtained and then the sample size was allocated with proportional to size of the households in the kebeles. Pen was pinned at the centre of each kebeles to select the first house. Then the study participants were selected by systematic sampling technique from those who met the inclusion criteria.

\section{Data quality control}

To maintain data quality, data collection tool was checked and pretested. Initially semi-structured questionnaire with closed and open ended questions were prepared in English, and then translated to Amharic and back to English to check consistency. Experienced data collectors and supervisors were recruited for data collection and two day intensive training was given on the tool. Daily supervision was carried out to check the completeness and consistency of the questionnaire.

\section{Operational definition}

\section{Knowledge}

A person has adequate knowledge if he/she scores more than mean of the knowledge question and inadequate knowledge if answers less than mean of the knowledge questions.

\section{Study variables}




\section{Dependent variables}

- Knowledge

- Attitude

\section{Independent variables}

- Social-demographic variables

- Personal hygiene factors

- Environmental sanitation factors

- Health system variables

\section{Data collection}

Pretested, structured interviewer administered questionnaire that includes knowledge, attitude, socialdemographic questions, personal hygiene, and environmental sanitation were used for data collection. Individuals who fulfil the inclusion criteria were identified by trained data collectors in the study area. Sixteen data collectors who were BSc or more degree holder and two supervisors were recruited for this study.

\section{Data processing and analysis}

Epi info version 7 was used for coding, entering and cleaning the collected data and the data were imported and analyzed by using SPSS version 20 . Bivariate analysis was done to determine the associations between each independent variables and outcome variable. All associated factors with $\mathrm{p}$ value less than 0.25 during bivariate analysis were entered in to multivariable logistic regression model. Odds ratio with $95 \%$ confidence intervals were used to see the strength of association between different variables. P-value and $95 \%$ confidence interval $(\mathrm{Cl})$ for odds ratio (OR) were used in deciding the significance of the associations. Before inclusion of independent factors, multi-collinearity was checked using cut-off points Variance Inflation Factor $(\mathrm{VIF})<10$ and normality was checked by Q-Q probability plots. Hosmer-Lemeshow goodness of fit was also checked for the model at P-value $>0.05$.

\section{Ethical approval}

Ethical approval was obtained from Arba Minch University (AMU) Institute Research Review Board (IRB). Support letter was obtained from the district health offices to facilitate the data collection. Informed verbal consent was obtained from each study participants before proceeding to data collection. The objective of the study was explained for each selected kebele administration. All individuals were advised about the disease complication and its prevention measures after data collection.

Result

\section{Socio-demographic characteristics of the study subjects}


A total of 796 study participants from five kebeles of Arba Minch zuria district were interviewed with response rate of $98.2 \%$. The mean age of the study subjects was 38.9 with standard deviation of \pm 11.6 years. The minimum and maximum ages were 18 and 90 years old, respectively. Most 462 (58\%) of the respondents were males. More than half of the participants were Protestant religion believers followed by Orthodox, 459 (57.7\%) and 333(41.8\%) respectively. Regarding level of education, 345 (43.3\%), 321(40.3) and $130(16.3 \%)$ of the study subjects had no formal education, grade 1 to 8 and grade 9 and above, respectively. In our study, $666(83.7 \%)$ and $85(10.7 \%)$ of the respondents were married and single in their marital status, respectively (Table 1 ).

\section{Clinical characteristics, personal and environmental hygiene practice of study subjects}

Of the total respondents, $58(7.3 \%)$ and 56 (7\%) experienced eyelashes epilation and discharges present in their eyes. Regarding personal hygiene, $329(41.3 \%)$ of the study subjects wash face once per day and $109(13.7 \%)$ did not use soaps while washing their face. One hundred thirty $(16.3 \%)$ the participants had the habit of sharing clothes. On the other hand, faeces were present on the environment of $63(7.9 \%)$ of the study participants. Forty two (5.3\%) said that they have no latrine at all. More than half $459(57.7 \%)$ of the study subjects home was about more than one hour walking distance far away from health facility. Eighty five (10.7\%) the participants said that walking distance from their home to clean water source was more than 30 minutes (Table 2).

\section{Knowledge of community towards trachoma and trichiasis}

All $796(100 \%)$ of the study subjects were ever heard about trachoma. However, $366(46 \%)$ and 436 $(54.8 \%)$ of them did not ever heard about trichiasis and trichiasis surgery, respectively. Two hundred sixty three $(33 \%)$ of the respondents correctly answered the cause of trachoma. Regarding transmission of trachoma, $167(21 \%), 160(20.1 \%)$ and $592(74.4 \%)$ of the study subjects correctly responded that contact with discharges, sharing clothes or fomites and unhygienic environment were root of transmission for trachoma, respectively. Less than one forth $185(23.2 \%)$ of the study subjects had adequate knowledge towards trachoma (Table 3 ).

The source of knowledge for trachoma were health professionals 447 (56.2\%), radio/TV 203 (25.5\%), friends/neighbours $164(20.6 \%)$ and others 95 (11.9\%) (Figure 1).

\section{Attitude of study participants about trachoma and trichiasis}

According to this study 148 (18.6\%) strongly agreed that trachoma can be transmitted through gene. On the other hand, $240(30.1 \%)$ neutral and $144(18.1 \%)$ disagreed that trichiasis patients may loss vision if not operated. Half, $398(50 \%)$ of the study subjects disagreed that people with trichiasis can perform 
work like anyone without trichiasis. Ninety three (11.7\%) and 185 (23.2\%) of the respondents strongly agree and agree that they fear that trichiasis surgery by itself cause blindness, respectively (Table 4).

\section{Factors associated with knowledge of study participants about trachoma and trichiasis}

In bivariate analysis, gender, education, marital status, family size, occupation, wealth index, distance from home to health facility and clean water supply were candidate for multivariable logistic regression analysis.

In multivariable logistic regression analysis, education, occupation, walking distance from home to clean water source and wealth index were significantly associated with knowledge status of the participants. Study subjects who had no formal education and grade $1-8$ were $36.5 \%$ and $58 \%$ less likely to have adequate knowledge when compared to the counterpart, respectively.

Study subjects who had no formal education and primary grade level were lower chance of having adequate knowledge towards trachoma and trichiasis than those who were grade 9 and above educational background (AOR=0.365, 95\%Cl: $0.212,0.626)$ and (AOR= 0.58, 95\% Cl: $0.35,0.962)$, respectively. Similarly those who were farmers, merchants, students and housewife were less likely to have adequate knowledge than others (Gov't NGO workers). The study subjects who fetch clean water by walking 30 minutes or lower were 2.5 times more likely to have adequate knowledge than the counterpart, $(\mathrm{AOR}=2.531,95 \% \mathrm{Cl}: 1.183,5.4150)$.

Those study participants who were highest wealth index percentile $51 \%, 62 \%$ and $64 \%$ more likely to have adequate knowledge than lowest, second and middle percentile, (AOR=0.49, 95\% Cl: 0.27, 0.878), $(A O R=0.38,95 \% \mathrm{Cl}: 0.21,0.69)$ and $(\mathrm{AOR}=0.36,95 \% \mathrm{Cl}: 0.199,0.658)$, respectively (Table 5).

\section{Discussion}

In the current study all of the respondents had ever heard about trachoma infection. This result was almost similar with study conducted in Northern (89.2\%), Southern Ethiopia (92.6\%) and Bangladesh $(86 \%)(21,22,23)$. However, it is much higher than research report from Kenya in which about $65.7 \%$ of the respondents ever heard about trachoma (24). This might indicate that community mobilization and sensitization has been conducted in the study sites.

Finding of this study have shown that only $23.2 \%$ of the study subjects had adequate knowledge about trachoma and trichiasis infection. Only $33 \%$ of the subjects correctly answered the cause of trachoma. Significant number of the respondents (46\%) and (54.8\%) did not ever heard about trichiasis and trichiasis surgery, respectively. This result is much lower than study done in Zala district in which in which about $60 \%$ of the households had adequate knowledge towards trachoma (21). The possible explanation 
for this finding might be community based trachoma intervention especially on the awareness creation has been decreased from time to time and concerned bodies are shifted their duties on the other issues.

The present study revealed that $21 \%, 20.1 \%$ and $74.4 \%$ of the respondents reported correctly that trachoma can be transmitted through contact with discharges, sharing clothes or fomites and unhygienic environment, respectively. This finding is in line with studies done in Kenya in that only one third and 35\% of the participants correctly knew that flies and not washing face were important predictors for the transmission of trachoma disease, repectively (25).

According to this study, $18.6 \%$ strongly agreed and more than $25 \%$ unsure that trachoma can be transmitted through gene. On the other hand, $11.7 \%$ and $23.2 \%$ of the respondents strongly agreed and agreed that they fear that trichiasis surgery by itself cause blindness, respectively. The likely reason would be lack of awareness of the participants towards trachoma and trichiasis.

The present study showed that education of the respondents was significantly associated with knowledge on trachoma. Those study subjects who had no formal education and grade 1-8 were $36.5 \%$ and $58 \%$ less likely to have adequate knowledge when compared to the counterpart, respectively. This result is consistent with study done in Kenya in which significant proportion of individuals who had no formal and primary education had inadequate knowledge regarding trachoma (25). The possible explanation of this finding would be the fact that people who had higher educational background had better exposure to different media and information.

Those respondents who were working in no-governmental or governmental organizations had significantly adequate knowledge on trachoma and trichiasis than others. Being farmer, merchant, student and housewife were negatively associated with adequate knowledge. Although these are most risk group for trachoma infection, they had inadequate knowledge towards the disease.

The study subjects who fetch clean water by walking 30 minutes or less were 2.5 times more likely to have adequate knowledge than those who fetch water from above 30 minute walking distance. This might be due to people who had no access to clean water supply might also far away from social media accessibility. They might have poor infrastructures including health service, information, education and communications (IECs) might be inadequate in the area.

Individuals with highest wealth percentiles had positively higher chance of having adequate knowledge than other percentiles. People who have better economic status will have better opportunities of access to social media and communication with educated persons.

\section{Conclusion And Recommendation}

In the study area of Arba Minch zuria district, the proportion of people who had adequate knowledge about trachoma and trichiasis was low. Education, occupation, walking distance from home to clean water source and wealth index were significantly associated with knowledge status of the participants. 
Attention should be given by the district health office, regional government and different stakeholders, who designing and implementing trachoma elimination programs especially improving awareness of community regarding trachoma and trichiasis. Interventions with the F and E components of SAFE strategy are also strongly recommended.

\section{Abbreviations}

AMU, Arba Minch University; AOR, Adjusted Odds Ratio; Cl, Confidence Interval; CO, Corneal Opacity; IECs, Information, Education and Communication; IRB, Institute Research Review Board; NGO, NonGovernmental Organization; OR, Odds Ratio; SAFE, Surgery, Antibiotic, Facial cleanliness, Environmental hygiene; SNNPR, Southern Nation Nationality Region; SPSS, Statistical Package for Social Sciences; TF, Trachomatous Follicular; TI, Trachomatous Intense; TS, Trachomatous Scaring; Trachomatous Trichiasis; VIF, Variance Inflation Factor; WHO, World Health Organization.

\section{Declarations}

\section{Acknowledgement}

We would like to express our deepest gratitude and appreciation to lord of wisdom, God. We are grateful to Arba Minch University Collaborative Research Training Centre for Neglected Tropical Diseases for their full sponsorship of this research work. We are also grateful to all data collectors and supervisors, who tried their best and committed themselves to data collection.

\section{Ethical Approval and Consent to participate}

Ethical approval was obtained from Arba Minch University (AMU) Institute Research Review Board (IRB). Support letter was obtained from the district health offices to facilitate the data collection. Informed verbal consent was obtained from each study participants before proceeding to data collection. The objective of the study was explained for each selected kebele administration. All individuals were advised about the disease complication and its prevention measures after data collection.

\section{Consent for publication}

- Not applicable

\section{Availability of data and materials}

- The datasets during and/or analysed during the current study are available from the corresponding author on reasonable request. 


\section{Funding}

- This study was funded by the Arba Minch University, College of Medicine and Health Sciences, collaborative research and training centre.

\section{Conflict of interest}

- The authors declare that they have no competing interests.

\section{Authors' contribution}

All authors made a significant contribution to the work reported, whether that is in the conception, study design, execution, acquisition of data, analysis and interpretation, or in all these areas; took part in drafting, revising or critically reviewing the article; gave final approval of the version to be published; have agreed on the journal to which the article has been submitted; and agree to be accountable for all aspects of the work.

\section{References}

1. Bickley RJ, Mkocha H, Munoz B, West S. Identifying patient perceived barriers to trichiasis surgery In Kongwa District, Tanzania. PLoS neglected tropical diseases. 2017 Jan 4;11(1):e0005211.

2. Mariotti A, Pascolini D. Global estimates of visual impairment. Br J Ophthalmol. 2012;96(5):614-8.

3. World Health Organization. World Health Organization Alliance for the Global Elimination of Trachoma by 2020: second global scientific meeting on trachomatous trichiasis: Cape Town, 4-6 November 2015. World Health Organization; 2016.

4. Lavett DK, Lansingh VC, Carter MJ, Eckert KA, Silva JC. Will the SAFE strategy be sufficient to eliminate trachoma by 2020? Puzzlements and possible solutions. The Scientific World Journal. 2013 Oct; 2013.

5. World Health Organization. Future approaches to trachoma control: report of a global scientific meeting, Geneva, 17-20 June 1996. World Health Organization; 1997.

6. WHO. Alliance for the Global Elimination of Trachoma by 2020. Eliminating Trachoma: Accelerating Towards 2020. 2016.

7. Merbs S. Trichiasis surgery for trachoma. World Health Organization; 2013.

8. Rajak SN, Collin JR, Burton MJ. Trachomatous trichiasis and its management in endemic countries. Survey of ophthalmology. 2012 Mar 1;57(2):105 - 35.

9. World Health Organization. Report of the 2nd Global scientific meeting on trachoma: Geneva, 25-27 August, 2003. World Health Organization; 2003. 
10. Taylor HR, Burton MJ, Haddad D, West S, Wright H. Trachoma The Lancet. 2014 Dec;13(9960):214252. 384.

11. WHO. Trachoma weekly epidemiological records; 2019.

12. Habtamu E, Wondie T, Aweke S, et al. Trachoma and Relative Poverty: A Case-control study. PLoS Negl Trop Dis; 2015.

13. Wolle MA, Cassard SD, Gower EW, et al: Impact of Trichiasis surgery on physical functioning in Ethiopian patients: STAR trial. Am J Ophthalmol. 2011.

14. Doris WNyojoma, et al. Knowledge, practices and perceptions of trachoma and its control among communities of Narok couty. Kenya: Tropical Diseases, Travel Medicine and Vaccines; 2016.

15. Taylor, et al: Trachoma: a blinding scouragefrom the bronze age to twenty first century, Melbourne: 20008. Centre for eye research Austrialia.

16. Tara B, Mtuy, et al. Knowledge, perceptions and experiences of trachoma among Maasai in Tanzania: Implications for prevention and control. Journ PLOS Neglected Tropical Diseases; 2019.

17. WHO. Trachoma weekly epidemiological records; 2018.

18. Meshesha TD, et al. Determinants for not using Trachomatous trichiasis surgery in Mehalsayint District, North-East Ethiopia; 2018; PLoS Negl Trop Dis 12(7): e0006669.

19. Berhane $Y$, et al. National survey on blindness, low vision and trachoma in Ethiopia.

20. Methods and study clusters profile. (2006). Ethiop.J.HealthDev. 2007; 21(3):185-203.

\section{ORBIS International. International coalation for trachoma control,} http://www.trachomacoalition.org/about-ictc/members/orbis-international, accessed in October, 23/2019.

22. Mengistu, et al. prevalence and factors associated with trachoma among children aged 1-9 years old in Zala district. Southern Ethiopia: Gamo Goffa zone; 2014.

23. Islam FMA, Chakrabarti R, Islam SZ, Finger RP, Critchley C. "Factors associated with awareness, attitudes and practices regarding common eye diseases in the general population in a rural district in Bangladesh: the Bangladesh population-based diabetes and eye study (BPDES)," PLoS One, vol. 10, no. 7, 2015.

24. Hailay, Gebretnsae. Nega Mamo, Tesfay Teklemariam, Kiros Fenta .

25. Tesfay Gebrehiwet A, Berhe F, Gebreselasie, Demoz K. Knowledge, Attitudes, and Practices about Trachoma in Rural Communities of Tigray Region, Northern Ethiopia: Implications for Prevention and Control. Journal of Environmental and Public Health, Volume 2020, Article ID 3270530, 8 pages https://doi.org/10.1155/2020/3270530.

26. Ng'etich AS, Owino C, Juma A, Khisa KN. Knowledge, attitudes and eye care seeking practices regarding trachoma in Central Division of Kajiado County, Kenya. Journal of public health in Africa. 2015 Mar 31;6(1).

27. Pennina Nduku Munguti. Knowledge, practices and perceptionss of trachoma and its' influence (association with) on health seeking behaviour of patients in kajiado central sub county, kajiado 
county, kenya.2016.

\section{Tables}

Table 1: Socio-demographic characteristics of the study subjects, $(N=796)$.

\begin{tabular}{|c|c|c|c|}
\hline Variables & Category & Frequency & Percentage \\
\hline \multirow{5}{*}{ Age } & 19 or less years old & 9 & 1.1 \\
\hline & 20-29 years old & 152 & 19.1 \\
\hline & 30-39 years old & 305 & 38.3 \\
\hline & 40-49 years old & 194 & 24.4 \\
\hline & 50 and above years old & 136 & 17.1 \\
\hline \multirow[t]{2}{*}{ Gender } & Male & 462 & 58 \\
\hline & Female & 334 & 42 \\
\hline \multirow[t]{3}{*}{ Religion } & Orthodox & 333 & 41.8 \\
\hline & Protestant & 459 & 57.7 \\
\hline & Others $^{\square}$ & 4 & 0.5 \\
\hline \multirow[t]{3}{*}{ Ethnicity } & Gamo & 751 & 94.3 \\
\hline & Wolayta & 27 & 3.4 \\
\hline & Others $^{\ddagger}$ & 18 & 2.3 \\
\hline \multirow[t]{3}{*}{ Educational status } & No formal education & 345 & 43.3 \\
\hline & grade 1-8 & 321 & 40.3 \\
\hline & 9 and above grades & 130 & 16.3 \\
\hline \multirow[t]{4}{*}{ Marital status } & Married & 666 & 83.7 \\
\hline & Divorced & 5 & 0.6 \\
\hline & Single & 85 & 10.7 \\
\hline & Widowed & 40 & 5 \\
\hline \multirow[t]{6}{*}{ Occupation } & Farmer & 445 & 55.9 \\
\hline & Merchant & 104 & 13 \\
\hline & Student & 63 & 7.9 \\
\hline & Housewife & 159 & 20 \\
\hline & Day labourer & 10 & 1.3 \\
\hline & Others (C) & 15 & 1.9 \\
\hline \multirow[t]{2}{*}{ Family size } & 4 or less & 308 & 38.7 \\
\hline & Above 4 & 488 & 61.3 \\
\hline \multirow[t]{5}{*}{ Wealth index } & lowest percentile & 155 & 19.5 \\
\hline & Second percentile & 161 & 20.2 \\
\hline & meddle percentile & 164 & 20.6 \\
\hline & Fourth percentile & 160 & 20.1 \\
\hline & Highest percentile & 156 & 19.6 \\
\hline
\end{tabular}

$\left({ }^{\bigotimes}\right.$ Catholic and Adventist; ${ }^{\ddagger}$ Amhara and Goffa; @NGO, Gov't)

Table 2: Clinical, personal and environmental characteristics of the study participants, 2021. 


\begin{tabular}{|c|c|c|c|}
\hline Variables & Category & Frequency & Percentage \\
\hline \multirow[t]{2}{*}{ Experiencing eyelashes epilation } & Yes & 58 & 7.3 \\
\hline & No & 738 & 92.7 \\
\hline \multirow[t]{2}{*}{ Presence of discharge from the eyes } & Yes & 56 & 7 \\
\hline & No & 740 & 93 \\
\hline \multirow[t]{3}{*}{ Frequency of washing face } & Once per day & 329 & 41.3 \\
\hline & Twice per day & 289 & 36.3 \\
\hline & Three times per day & 178 & 22.4 \\
\hline \multirow[t]{2}{*}{ Use soaps while washing face } & Yes & 687 & 86.3 \\
\hline & No & 109 & 13.7 \\
\hline \multirow[t]{2}{*}{ Habit of sharing clothes } & Yes & 130 & 16.3 \\
\hline & No & 666 & 83.7 \\
\hline \multirow[t]{3}{*}{ Environmental cleanliness } & $\begin{array}{l}\text { Faeces present on the } \\
\text { ground }\end{array}$ & 63 & 7.9 \\
\hline & $\begin{array}{l}\text { Flies present on the } \\
\text { environment }\end{array}$ & 490 & 61.6 \\
\hline & Clean environment & 243 & 30.5 \\
\hline \multirow[t]{3}{*}{ Latrine conditions } & No latrine & 42 & 5.3 \\
\hline & Pit latrine & 749 & 94.1 \\
\hline & VIP latrine & 5 & 0.6 \\
\hline \multirow{2}{*}{$\begin{array}{l}\text { Walking distance from home to } \\
\text { health facility }\end{array}$} & One or less hour & 337 & 42.3 \\
\hline & Above one hour & 459 & 57.7 \\
\hline \multirow{2}{*}{$\begin{array}{l}\text { Walking distance from home to } \\
\text { clean water source }\end{array}$} & 30 minute or below & 711 & 89.3 \\
\hline & Above 30 minutes & 85 & 10.7 \\
\hline
\end{tabular}

Table 3: Knowledge of community towards trachoma and trichiasis in Arba Minch zuria district, Gamo zone, Southern Ethiopia, 2020. 


\begin{tabular}{|c|c|c|c|}
\hline Variables & Category & Frequency & $\begin{array}{l}\text { Percentage } \\
\%\end{array}$ \\
\hline Heard about trachoma & $\overline{\text { Yes }}$ & 796 & 100 \\
\hline \multirow[t]{5}{*}{ Cause of trachoma } & Bacteria & 263 & 33 \\
\hline & Dust & 400 & 50.3 \\
\hline & Curse & 72 & 9.1 \\
\hline & Virus & 55 & 6.9 \\
\hline & Others $^{\circledR}$ & 6 & 0.8 \\
\hline \multirow[t]{5}{*}{ Signs and symptoms } & Tearing of the eye & 337 & 42.3 \\
\hline & Redness of the eye & 375 & 47.1 \\
\hline & Scratching of the eyelashes & 146 & 18.3 \\
\hline & Photophobia & 156 & 19.6 \\
\hline & Itching & 284 & 35.7 \\
\hline \multirow[t]{3}{*}{$\begin{array}{l}\text { Transmission of } \\
\text { trachoma }\end{array}$} & $\begin{array}{l}\text { Contact with nasal or eye } \\
\text { discharges }\end{array}$ & 167 & 21 \\
\hline & Sharing clothes or fomites & 160 & 20.1 \\
\hline & Unhygienic environment & 592 & 74.4 \\
\hline \multirow[t]{4}{*}{ Prevention } & Use medicine & 452 & 56.8 \\
\hline & $\begin{array}{l}\text { Daily hand wash with water and } \\
\text { soap }\end{array}$ & 448 & 56.3 \\
\hline & $\begin{array}{l}\text { Avoid contact with nasal or eye } \\
\text { discharges }\end{array}$ & 159 & 20 \\
\hline & Avoid sharing clothes & 69 & 8.7 \\
\hline \multirow[t]{2}{*}{ Consequences } & Vision loss & 476 & 60 \\
\hline & Scaring of the eye & 142 & 17.8 \\
\hline \multirow{2}{*}{$\begin{array}{l}\text { Ever heard about } \\
\text { trichiasis }\end{array}$} & Yes & 430 & 54 \\
\hline & No & 366 & 46 \\
\hline \multirow{2}{*}{$\begin{array}{l}\text { Ever heard about TT } \\
\text { surgery }\end{array}$} & Yes & 360 & 45.2 \\
\hline & No & 436 & 54.8 \\
\hline \multirow{2}{*}{$\begin{array}{l}\text { Knowledge status of } \\
\text { patient }\end{array}$} & Adequate & 185 & 23.2 \\
\hline & Inadequate & 611 & 76.8 \\
\hline
\end{tabular}

(Others ${ }^{\circledR}=$ contaminated water, don't know)

Table 4: Attitude of study subjects towards trachoma and trichiasis in Arba Minch zuria district, Gamo zone, Southern Ethiopia, 2020. 


\begin{tabular}{|c|c|c|c|c|c|}
\hline \multirow[t]{2}{*}{ Variables } & \multicolumn{5}{|c|}{ Likart scale } \\
\hline & $\begin{array}{l}\text { Strongly } \\
\text { agree (1) }\end{array}$ & $\begin{array}{l}\text { Agree } \\
(2)\end{array}$ & $\begin{array}{l}\text { Neutral } \\
\text { (3) }\end{array}$ & $\begin{array}{l}\text { Disagree } \\
(4)\end{array}$ & $\begin{array}{l}\text { Strongly } \\
\text { disagree } \\
\text { (5) }\end{array}$ \\
\hline $\begin{array}{l}\text { Trachoma can be transmitted } \\
\text { through gene }\end{array}$ & $\begin{array}{l}148 \\
(18.6 \%)\end{array}$ & $\begin{array}{l}82 \\
(10.3 \%)\end{array}$ & $\begin{array}{l}204 \\
(25.6 \%)\end{array}$ & $\begin{array}{l}316 \\
(39.7 \%)\end{array}$ & $\begin{array}{l}46 \\
(5.8 \%)\end{array}$ \\
\hline $\begin{array}{l}\text { Trichiasis patients may loss } \\
\text { vision if not operated }\end{array}$ & $\begin{array}{l}100 \\
(12.6 \%)\end{array}$ & $\begin{array}{l}305 \\
(38.3 \%)\end{array}$ & $\begin{array}{l}240 \\
(30.1 \%)\end{array}$ & $\begin{array}{l}144 \\
(18.1 \%)\end{array}$ & $\begin{array}{l}7 \\
(0.9 \%)\end{array}$ \\
\hline $\begin{array}{l}\text { People with trichiasis can } \\
\text { perform work like anyone } \\
\text { without trichiasis }\end{array}$ & $69(8.7 \%)$ & $\begin{array}{l}149 \\
(18.7 \%)\end{array}$ & $\begin{array}{l}157 \\
(19.7 \%)\end{array}$ & $\begin{array}{l}398 \\
(50 \%)\end{array}$ & $\begin{array}{l}23 \\
(2.9 \%)\end{array}$ \\
\hline $\begin{array}{l}\text { I am willing to undergo surgery if } \\
\text { I have trichiasis }\end{array}$ & 87 (10.9\%) & $\begin{array}{l}354 \\
(44.5 \%)\end{array}$ & $\begin{array}{l}166 \\
(20.8 \%)\end{array}$ & $\begin{array}{l}167 \\
(21 \%)\end{array}$ & $\begin{array}{l}22 \\
(2.8 \%)\end{array}$ \\
\hline $\begin{array}{l}\text { I will not prefer epilation of in } \\
\text { warded eye lashes rather than } \\
\text { surgery }\end{array}$ & $155(19.5 \%)$ & $\begin{array}{l}384 \\
(48.2 \%)\end{array}$ & $\begin{array}{l}122 \\
(15.3 \%)\end{array}$ & $\begin{array}{l}120 \\
(15.1 \%)\end{array}$ & $\begin{array}{l}15 \\
(1.9 \%)\end{array}$ \\
\hline $\begin{array}{l}\text { I believe that trichiasis can be } \\
\text { prevented }\end{array}$ & $184(23.1)$ & $\begin{array}{l}420 \\
(52.8 \%)\end{array}$ & $\begin{array}{l}142 \\
(17.8 \%)\end{array}$ & $40(5 \%)$ & $\begin{array}{l}10 \\
(1.3 \%)\end{array}$ \\
\hline $\begin{array}{l}\text { Trachoma can be transmitted } \\
\text { from one person to another }\end{array}$ & $\begin{array}{l}152 \\
(19.1 \%)\end{array}$ & $\begin{array}{l}311 \\
(39.1 \%)\end{array}$ & $\begin{array}{l}233 \\
(29.3 \%)\end{array}$ & $\begin{array}{l}78 \\
(9.8 \%)\end{array}$ & $\begin{array}{l}22 \\
(2.8 \%)\end{array}$ \\
\hline $\begin{array}{l}\text { I fear that trichiasis surgery by } \\
\text { itself cause blindness }\end{array}$ & 93 (11.7\%) & $\begin{array}{l}185 \\
(23.2 \%)\end{array}$ & $\begin{array}{l}221 \\
(27.8 \%)\end{array}$ & $\begin{array}{l}240 \\
(30.2 \%)\end{array}$ & $\begin{array}{l}57 \\
(7.2 \%)\end{array}$ \\
\hline
\end{tabular}

Table 5: Factors associated with knowledge of study participants towards trachoma and trichiasis in Arba Minch zuria district, Gamo zone, SNNPR, Ethiopia, 2020. 


\begin{tabular}{|c|c|c|c|c|c|}
\hline \multirow[t]{2}{*}{ Variables } & \multirow[t]{2}{*}{ Category } & \multicolumn{2}{|c|}{ Knowledge status } & \multirow{2}{*}{ AOR, 95\%CI } & \multirow[t]{2}{*}{ P-value } \\
\hline & & Adequate & Inadequate & & \\
\hline \multirow[t]{2}{*}{ Gender } & Male & 121 & 341 & $\begin{array}{l}1.174(0.73, \\
1.88)\end{array}$ & 0.506 \\
\hline & Female & 64 & 270 & Reference & \\
\hline \multirow[t]{3}{*}{ Education } & $\begin{array}{l}\text { No formal } \\
\text { education }\end{array}$ & 60 & 285 & $\begin{array}{l}0.365(0.212, \\
0.626)\end{array}$ & $0.001^{* *}$ \\
\hline & $\begin{array}{l}\text { Grade 1-8 } \\
\text { (primary } \\
\text { school) }\end{array}$ & 75 & 246 & $\begin{array}{l}0.58(0.35 \\
0.962)\end{array}$ & $0.035^{*}$ \\
\hline & $\begin{array}{l}\text { Grade } 9 \text { and } \\
\text { above }\end{array}$ & 50 & 80 & Reference & \\
\hline \multirow[t]{4}{*}{ Marital status } & Married & 159 & 507 & $\begin{array}{l}\text { 2.056(0.697, } \\
6.064)\end{array}$ & 0.191 \\
\hline & Divorced & 0 & 5 & $0.0(0.0)$ & 0.99 \\
\hline & Single & 22 & 63 & $\begin{array}{l}2.444(0.660, \\
9.054)\end{array}$ & 0.181 \\
\hline & Widowed & 4 & 36 & Reference & \\
\hline \multirow[t]{2}{*}{ Family size } & 4 or less & 79 & 229 & $\begin{array}{l}1.225(0.845, \\
1.776)\end{array}$ & 0.284 \\
\hline & Above 4 & 106 & 382 & Reference & \\
\hline \multirow[t]{6}{*}{ Occupation } & Farmer & 113 & 332 & $\begin{array}{l}0.063(0.008, \\
0.52)\end{array}$ & $0.01 *$ \\
\hline & Merchant & 16 & 88 & $\begin{array}{l}0.022(0.003, \\
0.194)\end{array}$ & $0.001^{* *}$ \\
\hline & Student & 16 & 47 & $\begin{array}{l}0.026(0.003, \\
0.225)\end{array}$ & $0.001^{* *}$ \\
\hline & Housewife & 26 & 133 & $\begin{array}{l}0.03(0.004 \\
0.256)\end{array}$ & $0.001^{* *}$ \\
\hline & Day labourer & 0 & 10 & $0.0(0.0,-)$ & 0.999 \\
\hline & Others (C) & 14 & 1 & Reference & \\
\hline \multirow[t]{2}{*}{$\begin{array}{l}\text { Distance from home to } \\
\text { health facility }\end{array}$} & $\begin{array}{l}\text { One hour or } \\
\text { below }\end{array}$ & 70 & 267 & $\begin{array}{l}0.915(0.623, \\
1.344)\end{array}$ & 0.650 \\
\hline & $\begin{array}{l}\text { Above one } \\
\text { hour }\end{array}$ & 115 & 344 & Reference & \\
\hline \multirow{2}{*}{$\begin{array}{l}\text { Walking distance from } \\
\text { home to clean water } \\
\text { source }\end{array}$} & $\begin{array}{l}30 \text { minute or } \\
\text { below }\end{array}$ & 176 & 535 & $\begin{array}{l}\text { 2.531(1.183, } \\
5.4150)\end{array}$ & $0.017 *$ \\
\hline & $\begin{array}{l}\text { Above } 30 \\
\text { minutes }\end{array}$ & 9 & 76 & Reference & \\
\hline \multirow[t]{5}{*}{ Wealth index } & Lowest & 30 & 125 & $\begin{array}{l}0.49(0.27, \\
0.878)\end{array}$ & $0.016^{*}$ \\
\hline & Second & 29 & 132 & $\begin{array}{l}0.38(0.21 \\
0.69)\end{array}$ & $0.001 * *$ \\
\hline & Middle & 27 & 137 & $\begin{array}{l}0.36(0.199, \\
0.658)\end{array}$ & $0.001^{* *}$ \\
\hline & Fourth & 51 & 109 & $\begin{array}{l}1.0(0.59, \\
1.69)\end{array}$ & 0.99 \\
\hline & Highest & 48 & 108 & Reference & \\
\hline
\end{tabular}

(@NGO and Gov't workers; *statistically significant association; **strongly significantly associated) 
Figures

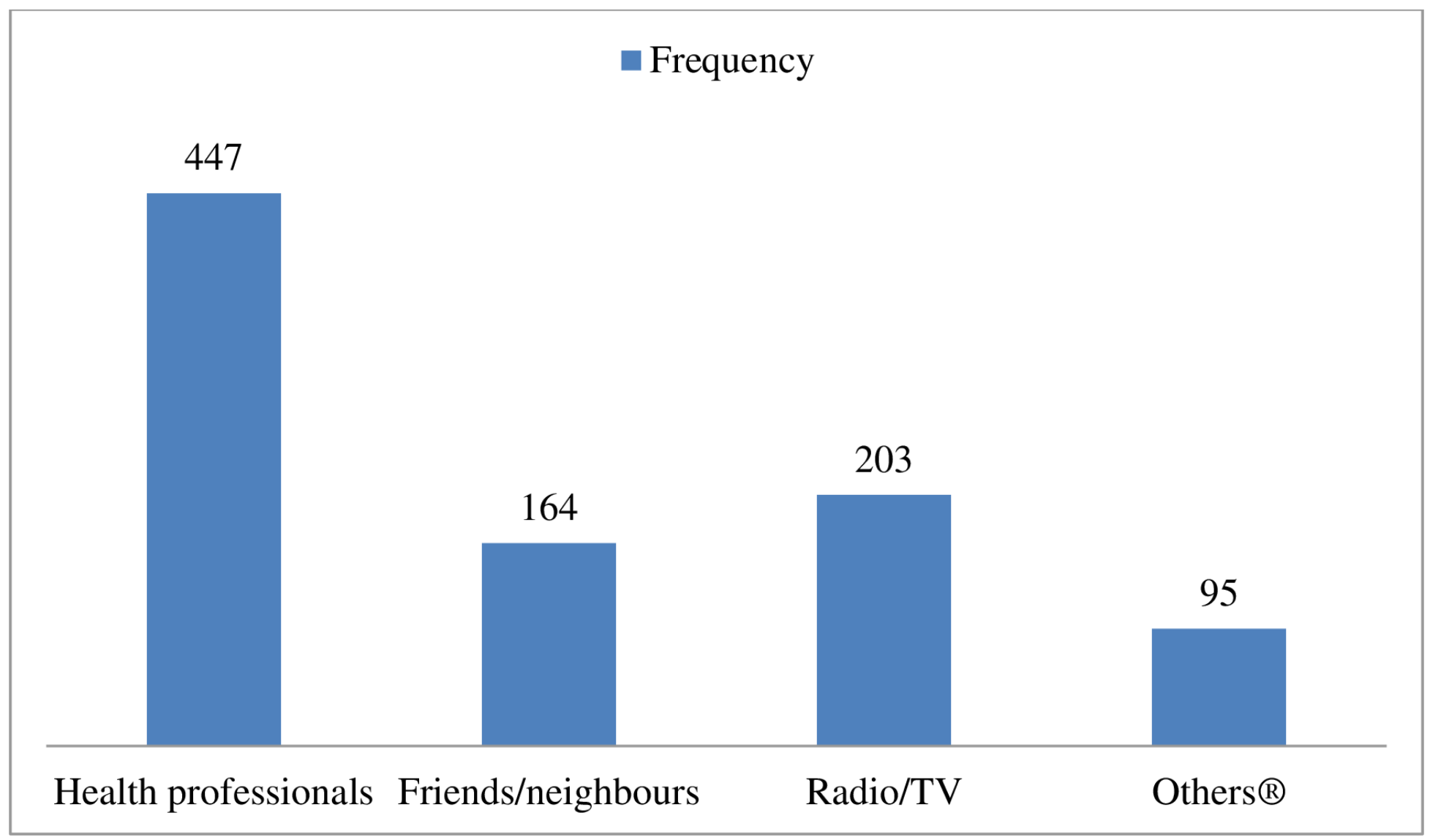

\section{Figure 1}

Sources of knowledge of study subjects towards trachoma and trichiasis in Arba Minch zuria district, Gamo zone, Southern Ethiopia, 2020. (Others $\AA=$ local meetings, church/mosques) 